\section{Assessing the correlation between metabolic parameters and risk factors in transition cows}

\section{ABSTRACT}

Our objective in this study was to evaluate the correlation between metabolic parameters included beta-hydroxybutyric acid, nonesterified fatty acids, magnesium, calcium, and lactate as being continuous variables and some factors (age, lactation number, lactation stage, body condition score, and feeding type) in transition cows. For this purpose, clinically healthy appearance Holstein cows $(n=53)$ from different farms were assessed for analysing at the transition period. Blood samples were collected and measuring of parameters were done with cow-side monitor weekly during the study. As a result, it has been seen that beta-hydroxybutyric acid, nonesterified fatty acids, and calcium were affected by the lactation stage with statistically significant $(\mathrm{p}<0.01)$. Moreover, effect of body condition score on nonesterified fatty acids was found to statistically higher in $2<$ body condition score $<3$ group $(p<0.05)$. Differently, mean calcium was established statistically important $(p<0.01)$ and higher feeding with total mix ration. The results of this study indicated that plasma beta-hydroxybutyric acid, nonesterified fatty acids, and calcium were affected by the lactation stage related to energy haemostasis in the transition period. Unlike, among other variables, lactate and magnesium were not changed in response to all factors.

Keywords: Transition period, cattle, correlation, model

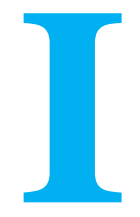

\section{NTRODUCTION}

The transition period being important physiological and metabolic alteration (Herdt, 2000) is defined as a time from the last 3 weeks of prepartum to postpartum (Grummer, 1993). This period induces negative energy balance (NEB) consisted as energy demands exceed the energy intake of lactation cows and NEB is initially resulted in the mobilization of fat from adipose tissue in the form of nonesterified fatty acids (NEFA) as required metabolic fuels for completing energy deficit (Sordillo and Raphael, 2013). On the other hand, some NEFA are partially oxidized to betahydroxybutyric acid (BHBA) or turned to triglycerides in the liver (Drackley et al., 2001; Reynolds et al., 2003). Elevation of these two metabolites (NEFA and BHBA) are considered as an indicator of NEB and cursor of early lactation diseases (Bicalho et al., 2017; Herdt, 2000; Ospina et al., 2010).

In addition to fat mobilization, the calcium $\left(\mathrm{Ca}^{+2}\right)$ homeostatic mechanism of lactation cows particularly impairs and increased $\mathrm{Ca}^{+2}$ requirements for supporting colostrum and milk synthesis brings about clinical and subclinical hypocalcemia (Goff, 2008).

\section{How to cite this article}

Erdoğan, S., Ural DA. (2020). Assessing the correlation between metabolic parameters and risk factors in transition cows. Journal of Advances in VetBio Science and Techniques, 5(3), 106-113. https://doi.org/10.31797/vetbio. 753680
Research Article

Songül ERDOĞAN ${ }^{1 \mathrm{a}}$

Deniz ALIÇ URAL ${ }^{2 b}$

\author{
${ }^{1}$ Department of Internal \\ Medicine, Aydın Adnan \\ Menderes University, \\ Veterinary Faculty \\ Aydın, Turkey \\ ${ }^{2}$ Faculty Farm, Aydın Adnan \\ Menderes University, \\ Veterinary Faculty, \\ Aydın, Turkey
}

ORCID-

${ }^{\text {a } 0000-0002-7833-5519 ~}$

b 0000-0002-2659-3495

Correspondence

Songül ERDOĞAN

songultp.09@gmail.com

Article info

Submission: 12-08-2020

Accepted: 24-11-2020

Online First: 18-12-2020

e-ISSN : 2548-1150

doi prefix: $10.31797 /$ vetbio

- http://dergipark.org.tr/vetbio

This work is licensed under a Creative Commons Attribution 4.0 International License (c) $\underset{\mathrm{EY}}{(7)}$ 
Especially subclinical hypocalcemia ignored for less clinical signs have associated with impaired immune function (Martinez et al., 2014) and some postpartum diseases (Caixeta et al., 2017; Rodríguez et al., 2017).

Out of these three commonly studied parameters, magnesium $\left(\mathrm{Mg}^{+2}\right)$ and lactate are considered as biomarkers in this study. $\mathrm{Mg}^{+2}$ as an intracellular cation regulates enzyme activation resulting in neural, hormonal, and metabolic control (Kleczkowski et al., 2013). Hypomagnesemia existing mostly in subclinical form was found frequently within lactation probably related to disease condition in epidemiologic study describing metabolic disease of transition cows (Erb et al., 1985; Fiorentin et al., 2018).

The major source of endogenous production of L-lactate is skeletal muscles and intestines but also occurs as a result of hypoperfusion or bacterial fermentation in tissues (Hove et al., 1999). Increased lactate concentration has a reliable prognostic value of determining the severity of endotoxemia and monitoring mortality in ruminants due to inflammatory conditions (Coghe et al., 2000). It is also reported that it can be variated during lactation for used as a source of gluconeogenesis in ruminants (Figueiredo et al., 2006).

The objective of this study was to evaluate the correlation between some metabolic parameters included BHBA, NEFA, $\mathrm{Mg}^{+2}$, $\mathrm{Ca}^{+2}$, and lactate as being continuous variables and some factors [age, lactation number, lactation stage, body conditions core (BCS) and feeding type] in transition cows.
MATERIALS and METHODS

\section{Animals and management}

This experiment was conducted in different commercial farms through March 2019September 2019. Totally 53 healthy appearance Holstein cows with different age and body weight to be formed 3 groups determined as prepartum (14 to $2 \mathrm{~d}$ ), parturition (0. d), and postpartum ( 2 to $14 \mathrm{~d}$ ) in the transition period were enrolled. Farms management was generally done to freestall housing equipped with self-locking headgates, feeding with total mixed ration (TMR) or separate feeding (SF) twice a day, ad libitum access to water, and milked two times a day. Visiting of farms was actualized weekly during the study.

\section{Blood analysis and parameters assay}

Blood samples were weekly withdrawn from coccygeal vein to each anticoagulant tubes including $\mathrm{K}_{3}$ EDTA and lithium heparin at prepartum (14 to $2 \mathrm{~d}$ ), parturition ( $0 . \mathrm{d}$ ), and postpartum ( 2 to $14 \mathrm{~d}$ ) period at 6 to 8 hours after early feeding. All samples including lithium heparin were centrifuged at $6000 \mathrm{rpm}$ by cow-side device (Sprout, Healthrow Scientific, USA) for separating to plasma following collection.

Heparinized plasma NEFA, $\mathrm{Mg}^{+2}, \mathrm{Ca}^{+2}$, and lactate were measured using biochemical solution working by enzymatic colorimetric method according to instructions of cow-side device (Vet Photometer 700 DP, Diaglobal, Germany). And also plasma BHBA was measured from blood samples including K3EDTA using enzymatic colorimetric method depending on the oxidation of BHBA to acetoacetate in presence of the BHBA dehydrogenase, after that, reduction of NAD+ to NADH with cow-side handheld device (Vet TD-4235 ß-Keto, Antalya, Turkey) (Figure 1). 

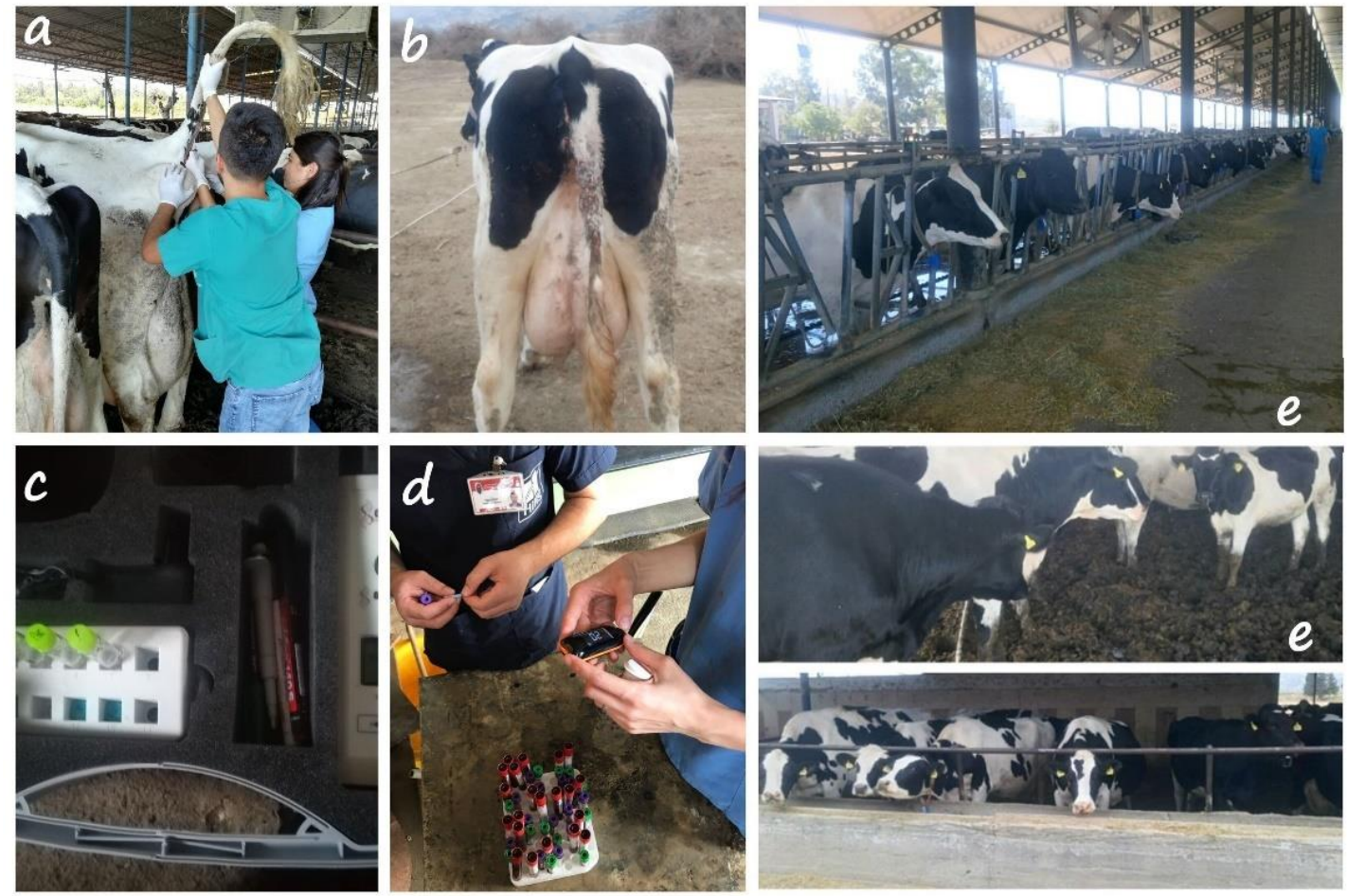

Figure 1. a) Taking blood from V. coccygea, b) Preparating of cows for BCS, c)-d) Cow-side devices for measuring of parameters, e) image of different farms breeding Holstein

Lastly, BCS was performed weekly according to Edmonson et al. (1989) and classified based on 1) $2<\mathrm{BCS}<3$, 2) $3<\mathrm{BCS}<4$, and 3) $4 \geq$ BCS for statistic model.

\section{Evaluation of data using multivariate analysis}

As continuous variables, BHBA, NEFA, $\mathrm{Mg}^{+2}$, $\mathrm{Ca}^{+2}$, and lactate parameters were evaluated to be the main risk factors. For revealing possible effects, statistical models were formed. The factors affecting to emphasized features were grouped among themselves during formed of models. Cows age ranged from 2 to 8 years and each age was considered as a one group. Lactation number to be primiparous (first lactation) and multiparous ( $\geq 2$ lactation) cows and lactation stage with prepartum (14 to $2 \mathrm{~d}$ ), parturition $(0 \mathrm{~d})$, and postpartum (2 to $14 \mathrm{~d})$ were evaluated as another factors. Feeding type was taken qua factor due to different ration contents including TMR and SF used in farms and being a reason of effect to emphasized features. Other factor BCS were grouped as $2<\mathrm{BCS}<3,3<\mathrm{BCS}<4$, and $4 \geq \mathrm{BCS}$.

From this viewpoint, the analysis of the obtained data was performed by using repeated measurement modeling. This model has subject for independent variables with multiple measurements at a certain time on the same individual.

The model included;

\section{Model I:}

$$
\begin{aligned}
& Y_{i j k l m n}=\mu+a_{i}+b_{j}+V k s d_{k l}+d_{l}+r_{m}+ \\
& \pi_{n(k)}+d \pi_{l n(k)}++e_{i j k l m n}
\end{aligned}
$$

$\mathrm{Y}_{\mathrm{ijklmn}}$ : i. age, j. lactation number, level $\mathrm{k}$ of BCS, 1. stage, m. feeding type, n. cow's BHBA concentration at transition period,

\section{Model II:}

$$
\begin{aligned}
& Y_{i j k l m n}=\mu+a_{i}+b_{j}+V k s d_{k l}+d_{l}+r_{m}+ \\
& \pi_{n(k)}+d \pi_{l n(k)}++e_{i j k l m n}
\end{aligned}
$$

$Y_{\mathrm{ijklmn}} \mathrm{i}$. age, j. lactation number, level $\mathrm{k}$ of BCS, 1. stage, m. feeding type, n. cow's NEFA concentration at transition period, 


\section{Model III:}

$Y_{i j k l m n}=\mu+a_{i}+b_{j}+V k s d_{k l}+d_{l}+r_{m}+$

$\pi_{n(k)}+d \pi_{\ln (k)}++e_{i j k l m n}$

$\mathrm{Y}_{\mathrm{ijklmn}}$ i. age, j. lactation number, level $\mathrm{k}$ of

BCS, 1. stage, m. feeding type, n. cow's lactate concentration at transition period,

\section{Model IV:}

$Y_{i j k l m n}=\mu+a_{i}+b_{j}+V k s d_{k l}+d_{l}+r_{m}+$ $\pi_{n(k)}+d \pi_{l n(k)}++e_{i j k l m n}$

$\mathrm{Y}_{\mathrm{ijklmn}}$ : i. age, j. lactation number, level $\mathrm{k}$ of BCS, 1. stage, m. feeding type, n. cow's $\mathrm{Mg}^{+2}$ concentration at transition period,

\section{Model V}

$$
\begin{aligned}
& Y_{i j k l m n}=\mu+a_{i}+b_{j}+V k s d_{k l}+d_{l}+r_{m}+ \\
& \pi_{n(k)}+d \pi_{l n(k)}++e_{i j k l m n}
\end{aligned}
$$

$\mathrm{Y}_{\mathrm{ijklmn}}$ : i. age, $\mathrm{j}$. lactation number, level $\mathrm{k}$ of BCS, 1. stage, m. feeding type, n. cow's $\mathrm{Ca}^{+2}$ concentration at transition period,

$\mu$ : population mean,

ai: the effect of age (i: $2,3,4,5,6,7,8)$

$b_{j}$ : the effect of lactation number ( $\mathrm{j}$ : primiparous (lactation number $=1$ ), multiparous (lactation number $>1$ and 2 to 5$)]$,

$\mathrm{BCS}_{\mathrm{k}}$ : the effect of body condition score (1: $2<\mathrm{BCS}<3,2: 3<\mathrm{BCS}<4,3: 4 \geq \mathrm{BCS}$ ),

$d_{1}$ is the effect of lactation stage [1:1 prepartum (14 to $2 \mathrm{~d}$ ), 2 parturition (0. d), 3 postpartum (2 to $14 \mathrm{~d})$ ],

$\mathrm{r}_{\mathrm{m}}$ : effect of feeding type [m: 1(TMR), 2 (SF)],

$\pi_{n(k)}$ : Random effect of experiment unit at level $\mathrm{k}$ of BCS

$V k s d_{k l}$ : Interaction effect,

$\mathrm{d} \pi_{\ln (\mathrm{k})}$ : Interaction effect among experiment unit and lactation stage at the level $\mathrm{k}$ of BCS eijklmn: residual error.

\section{Statistical analyses}

As continuous variables, BHBA, NEFA, $\mathrm{Mg}^{+2}$, $\mathrm{Ca}^{+2}$, and lactate parameters were evaluated to be the main risk factors. In the evaluation stage of the data obtained from the study, appropriate statistical methods were used to reveal both the possible relationships and differences between the features emphasized. For this purpose, it was used to MS Excel for the preparation of obtained data, SPSS 18 for determining descriptive statistics of emphasized features and analysis of variance, and Duncan Test was used for multiple comparison of subgroups (Duncan, 1995).

\section{Ethical scope}

This study was approved by Aydin Adnan Menderes University Animal Experiments Local Ethics Committee with number of 64583101/2016/104.

\section{RESULTS}

\section{Mean Values of Parameters}

Regarding data of BHBA, NEFA, $\mathrm{Mg}^{+2}, \mathrm{Ca}^{+2}$, and lactate were presented in Table 1 . The only effect of the lactation stage on BHBA concentration was observed statistically significant ( $p>0.01)$ and BHBA levels tended to increase from prepartum to postpartum period $(\mathrm{p}<0.01)$.

Likewise, BHBA, lactation stage also had a significant effect on NEFA concentration ( $p$ $<0.01)$. NEFA concentration of parturition and postpartum period was found to be approximate value, of prepartum was obtained lower, differently. On the other hand, evaluated of the relation between the BCS and NEFA, NEFA was found to statistically higher in $2<\mathrm{BCS}<3$ group ( $\mathrm{p}<0.05)$.

Similarly, BHBA, $\mathrm{Ca}^{+2}$ levels found to be increase from prepartum to postpartum period and parturition levels were found to be associated with other stages $(\mathrm{p}<0.01)$. 
Accordingly, effect of feeding type on mean $\mathrm{Ca}^{+2}$ levels were established statistically important $(\mathrm{p}<0.01)$ and higher in feeding with

TMR.
It was found that there was no effect of factors on lactate and $\mathrm{Mg}^{+2}$ concentrations.

Table 1. The least squares mean and standard errors of parameters according to the variables included in the model

\begin{tabular}{|c|c|c|c|c|c|c|}
\hline \multirow[t]{2}{*}{ Factors } & \multirow[t]{2}{*}{$\mathrm{n}$} & BHBA (mmol/L) & $\begin{array}{l}\text { NEFA } \\
(\mathrm{mEq} / \mathrm{L})\end{array}$ & Lactate (mmol/L) & $\mathrm{Mg}^{+2}(\mathrm{mmol} / \mathrm{L})$ & $\mathrm{Ca}^{+2}(\mathrm{mmol} / \mathrm{L})$ \\
\hline & & $\bar{X} \pm S_{\bar{X}}$ & $\bar{X} \pm S_{\bar{X}}$ & $\bar{X} \pm S_{\bar{X}}$ & $\bar{X} \pm S_{\bar{X}}$ & $\bar{X} \pm S_{\bar{X}}$ \\
\hline Age & & NS & NS & NS & NS & NS \\
\hline 2 & 8 & $0.86 \pm 0.125$ & $0.54 \pm 0.102$ & $1.46 \pm 0.195$ & $0.61 \pm 0.058$ & $1.66 \pm 0.249$ \\
\hline 3 & 6 & $0.94 \pm 0.642$ & $1.09 \pm 0.187$ & $1.67 \pm 0.272$ & $0.67 \pm 0.042$ & $1.72 \pm 0.239$ \\
\hline 4 & 11 & $0.817 \pm 0.107$ & $1.14 \pm 0.175$ & $1.77 \pm 0.193$ & $0.63 \pm 0.068$ & $1.83 \pm 0.092$ \\
\hline 5 & 7 & $1.16 \pm 0.13$ & $1.06 \pm 0.223$ & $2.69 \pm 0.713$ & $0.72 \pm 0.136$ & $1.69 \pm 0.129$ \\
\hline 6 & 9 & $0.82 \pm 0.18$ & $0.81 \pm 0.93$ & $1.81 \pm 0.394$ & $0.74 \pm 0.043$ & $1.66 \pm 0.161$ \\
\hline 7 & 8 & $0.85 \pm 0.125$ & $0.99 \pm 0.117$ & $1.67 \pm 0.302$ & $0.53 \pm 0.105$ & $1.71 \pm 0.143$ \\
\hline 8 & 4 & $1.19 \pm 0.177$ & $1.01 \pm 0.157$ & $1.88 \pm 0.273$ & $0.65 \pm 0.027$ & $1.53 \pm 0.188$ \\
\hline Lactation number & & NS & NS & NS & NS & NS \\
\hline Primiparous & 19 & $0.98 \pm 0.0 .114$ & $0.98 \pm 0.122$ & $1.87 \pm 0.307$ & $0.68 \pm 0.043$ & $1.65 \pm 0.126$ \\
\hline Multiparous & 34 & $0.88 \pm 0.043$ & $0.92 \pm 0.071$ & $1.82 \pm 0.137$ & $0.64 \pm 0.035$ & $1.73 \pm 0.067$ \\
\hline BCS & & NS & $*$ & NS & NS & NS \\
\hline $2<\mathrm{BCS}<3$ & 5 & $0.82 \pm 0.146$ & $1.35^{\mathrm{bc}} \pm 0.231$ & $2.06 \pm 0.295$ & $0.55 \pm 0.131$ & $1.60 \pm 0.189$ \\
\hline $3<\mathrm{BCS}<4$ & 37 & $0.89 \pm 0.042$ & $0.86^{\mathrm{a}} \pm 0.070$ & $1.79 \pm 0.132$ & $0.67 \pm 0.077$ & $1.73 \pm 0.077$ \\
\hline $\mathrm{BCS} \geq 4$ & 11 & $1.03 \pm 0.182$ & $1.05^{\mathrm{b}} \pm 0.137$ & $1.89 \pm 0.504$ & $0.65 \pm 0.027$ & $1.67 \pm 0.162$ \\
\hline Feeding type & & NS & NS & NS & NS & $* *$ \\
\hline TMR & 37 & $0.95 \pm 0.064$ & $0.94 \pm 0.80$ & $1.86 \pm 0.188$ & $0.65 \pm 0.029$ & $1.84^{\mathrm{a}} \pm 0.066$ \\
\hline SF & 16 & $0.84 \pm 0.067$ & $0.97 \pm 0.099$ & $1.77 \pm 0.160$ & $0.67 \pm 0.061$ & $1.40^{\mathrm{b}} \pm 0.102$ \\
\hline Lactation stage & & $* *$ & $* *$ & NS & NS & $* *$ \\
\hline prepartum (14 to 2 d) & 53 & $0.74^{\mathrm{a}} \pm 0.0031$ & $0.69^{\mathrm{a}} \pm 0.079$ & $1.82 \pm 0.213$ & $0.65 \pm 0.031$ & $1.20^{\mathrm{a}} \pm 0.79$ \\
\hline parturition $(0 . d)$ & 53 & $0.82^{\mathrm{a}} \pm 0.041$ & $1.10^{\mathrm{b}} \pm 0.123$ & $1.68 \pm 0.188$ & $0.66 \pm 0.047$ & $1.59^{\mathrm{ab}} \pm 0.131$ \\
\hline postpartum ( 2 to $14 \mathrm{~d})$ & 53 & $1.18^{\mathrm{b}} \pm 0.106$ & $1.04^{\mathrm{b}} \pm 0.110$ & $1.99 \pm 0.243$ & $0.66 \pm 0.046$ & $2.34^{\mathrm{b}} \pm 0.1$ \\
\hline
\end{tabular}

a.b.c: Significant differences between the subgroups of each variable and the mean with different letters on the same line, $*: p<0.05$, $* * \mathrm{p}<0.01$, NS : nonsignificant, TMR: total mix ration, SF: separate feeding, NEFA: non-esterified fatty acids, BHBA: beta hydroxy butyric acid, Mg: magnesium, Ca: calcium, BCS: body condition score

\section{DISCUSSION}

The purpose of this study was to evaluate the correlation between some metabolic parameters included BHBA, NEFA, $\mathrm{Mg}^{+2}, \mathrm{Ca}^{+2}$, and lactate as being continuous variables and some factors included age, lactation number, lactation stage, BCS, and feeding type in transition cows.

Observed data established that BHBA and NEFA increased with statistically significant towards postpartum period without NEFA value of postpartum $(p<0.001)$. Gradually increased BHBA levels towards postpartum might be related to decreased DMI around parturition (Drackley et al., 2005) with decreased oxaloacetate produced of rumen fermentation and mediated NEFA enter to TCA cycle in the

liver (Drackley et al., 2006; Grummer, 1993). On the other hand, it can be explained that anaplerotic pathway in which oxidized acetylCoA exceed TCA cycle capacity or exactly opposite cataplerotic pathway in which increased acetyl-CoA esterified to triglyceride or oxidized to ketone bodies of oxaloacetate: Acetyl-CoA balance in the liver (van Knegsel et al., 2005). Decreased NEFA levels in the 
advancing postpartum period can be supported that increased DMI related to feeding with high energy ration along with lactation and became loose of NEB (McGuire et al., 2004; Moallem et al., 2000).

Similarly, $\mathrm{Ca}^{+2}$ was gradually increased compared to lactation stage $(\mathrm{p}<0.01)$. As known decreased $\mathrm{Ca}^{+2}$ levels a few days before calving is quite a little at 12-24 hours after calving and get back to normal levels until three to four days later (Goff, 2008; Martinez et al., 2012). Considering to $\mathrm{Ca}^{+2}$ levels are lowest at postpartum first two days (Goff, 2008) and increase after postpartum 3rd day (Martinez et al., 2012), postpartum increased $\mathrm{Ca}^{+2}$ levels in our study may be explained with the feeding of dairy cows after calving, development of ruminal contraction (Wynn et al.,2015) and with postpartum blood analysis performed at $1 \mathrm{st}$ and 2 nd weeks not first 2 days in our study.

In relation with the effect of feeding type on parameters, there was only established statistical importance $(\mathrm{p}<0.01)$ on mean $\mathrm{Ca}^{+2}$ levels and higher feeding with TMR. The freedom of a cow for a preferred choice of forage, i.e alfa alfa hay or corn silage may be offered due to their unfamiliar protein and mineral contents. Given the roughness of a nutritional balanced diet animals time to time select a greater amount of calcium in relationship with alfa alfa hay diet in which might involve greater amounts of calcium (Muller et al., 1977; Schingoethe, 2017). Although flavor preferences for nourishing supplements (Coppok et al., 1981), TMR might decrease or eliminate feeding problems (Schingoethe, 2017) furthermore digestive absences or fed conditions excite less frequently with TMR feeding (Hernandez-Urdaneta et al., 1976). On the other hand, SF results in more balance nutrition whereas TMR diets are consumed more slowly which could influence $\mathrm{Ca}^{+2}$ metabolism (Schingoethe, 2017). Finally, cows were fed with TMR in state of SF judiciously devour several feed components in which this behavior has been dominated and there is seen in dairy cows selecting small particular of grain which could entirely affect $\mathrm{Ca}^{+2}$ metabolism. This may be briefly explained elevated and statistically significant observed $\mathrm{Ca}^{+2}$ levels of feeding with TMR.

Body condition score is a useful tool for evaluating body fat stores for estimating energy reserves in dairy cows and correlated with some metabolic parameters for observing lactation disease (Pires et al., 2013; Wildman et al., 1982). In our study, there had just been a relation between BCS and NEFA to being highest $(1.35 \pm 0.231 \mathrm{mEq} / \mathrm{L})$ in cows with lower BCS and lowest $(0.86 \pm 0.070 \mathrm{mEq} / \mathrm{L})$ in $3<\mathrm{BCS}<4$ group. Practically warranted optimum BCS in dairy cows breeding is 3.25 (3-3.5) especially at dry period and calving (Treacher et al., 1986; Wildman et al., 1982). According to Barletta et al. (2017), lower BCS of transition cows has been associated with higher NEFA and welfare. Increasing of milk yield in the early postpartum period with low dry matter intake in close-dry period brings about NEB in high yielding dairy cows with higher NEFA mobilization from adipose tissue (Treacher et al., 1986), and this station causes of excessive depletion of body reserves and be changing of body condition related to energy balance (Barletta et al., 2017). Our findings were parallel with the literature data related to NEFA levels that were determined to be higher in $2<$ BCS $<3$ group $(p<0.05)$ than the others.

The altered metabolic status of dairy cows by NEB was resulted in the mobilisation of more NEFA and BHBA to energy deficiency in the transition period and insufficiently metabolizing of NEFA in the liver. Excessive NEFA and BHBA negatively influence of postpartum cow health. Subclinical hypocalcemia with increased NEFA and BHBA has been linked to risk for uterine disease and postpartum culling. The results of this study indicated that plasma NEFA, BHBA, and $\mathrm{Ca}^{+2}$ concentrations were affected by the lactation 
stage related to energy hemostasis in the transition period. Unlike, among other variables, lactate and $\mathrm{Mg}^{+2}$ were not changed statistically in response to all factors.

\section{CONCLUSION}

One of the present authors' (S.E.) herein declare that this study was independent field research, in which she completed her $\mathrm{PhD}$ thesis like this subject. On the other hand, it must be notified that the subject, material, animal population, and conditions of the present study totally differ to her previous $\mathrm{PhD}$ study. The only similarity is that analyzes method and geographical variations, apart from several farms enrolled.

\section{REFERENCES}

Barletta, R. V., Maturana Filho, M., Carvalho, P. D., Del Valle, T. A., Netto, A. S., Rennó, F. P., \& Sartori, R. (2017). Association of changes among body condition score during the transition period with NEFA and BHBA concentrations, milk production, fertility, and health of Holstein cows. Theriogenology, 104,30-36. doi:10.1016/j.theriogenology.2017.07.030.

Bicalho, M. L. S., Marques, E. C., Gilbert, R. O., \& Bicalho, R. C. (2017). The association of plasma glucose, BHBA, and NEFA with postpartum uterine diseases, fertility, and milk production of Holstein dairy cows. Theriogenology, 88, 270-282.doi: 10.1016/j.theriogenology.2016.09.036.

Caixeta, L. S., Ospina, P. A., Capel, M. B., \& Nydam, D. V. (2017). Association between subclinical hypocalcemia in the first 3 days of lactation and reproductive performance of dairy cows. Theriogenology,94,1-7.doi: 10.1016/ j.theriogenology .2017.01.039.

Coghe, J., Uystepruyst, C. H., Bureau, F., Detilleux, J., Art, T., \& Lekeux, P. (2000). Validation and prognostic value of plasma lactate measurement in bovine respiratory disease. The Veterinary Journal, 160(2), 139-146. doi: 10.1053/tvj1.2000.0487.

Treacher, R. J., Reid, I. M., \& Roberts, C. J. (1986). Effect of body condition at calving on the health and performance of dairy cows. Journal of Animal Production, 43, 1-6.

Coppock, C. E., Bath, D. L., \& Harris Jr, B. (1981). From feeding to feeding systems. Journal of Dairy Science, 64(6), 1230-49.
Drackley, J. K., \& Andersen, J. B. (2006). Splanchnic metabolism of long-chain fatty acids in ruminants. In K. Sejrsen, T. Hvelplund, \& M.O. Nielsen (Eds.), Ruminant physiology: Digestion, metabolism and impact of nutrition on gene expression, immunology and stress, (199-224). Wageningen Academic Publishers.

Drackley, J. K., Dann, H. M., Douglas, N., Guretzky, N. A. J., Litherland, N. B., Underwood, J. P., \& Loor, J. J. (2005). Physiological and pathological adaptations in dairy cows that may increase susceptibility to periparturient diseases and disorders. Italian Journal of Animal Science, 4(4), 323-344. doi: 10.4081/ijas.2005.323.

Drackley, J. K., Overton, T. R., \& Douglas, G. N. (2001). Adaptations of glucose and long-chain fatty acid metabolism in liver of dairy cows during the periparturient period. Journal of Dairy Science, 84, 100-112. doi: 10.3168/jds.S0022-0302(01)70204-4.

Duncan, D. B. (1995). Multiple range and multiple F test. Biometric, 11(1), 1-42.

Edmonson, A. J., Lean, I. J., Weaver, L. D., Farver, T., \& Webster, G. (1989). A body condition scoring chart for Holstein dairy cows. Journal of Dairy Science, 72(1), 68-78. doi: 10.3168/jds.S00220302(89)79081-0.

Erb, H. N., Smith, R. D., Oltenacu, P. A., Guard, C. L., Hillman, R. B., Powers, P. A., \& White, M. E. (1985). Path Model of Reproductive Disorders and Performance, Milk Fever, Mastitis, Milk Yield, and Culling in Holstein Cows1. Journal of Dairy Science, $68(12)$, 3337-3349. doi: 10.3168/jds.S00220302(85)81244-3.

Figueiredo, M. D., Nydam, D. V., Perkins, G. A., Mitchell, H. M., \& Divers, T. J. (2006). Prognostic value of plasma L-lactate concentration measured cow-side with a portable clinical analyzer in Holstein dairy cattle with abomasal disorders. Journal of Veterinary Internal Medicine, 20(6), 1463-1470. doi: 10.1111/j.1939-1676.2006.tb00767.x.

Fiorentin, E. L., Zanovello, S., Gato, A., Piovezan, A. L., Alves, M. V., Rocha, R. X., \& Gonzalez, F. (2018). Occurrence of subclinical metabolic disorders in dairy cows from western Santa Catarina state, Brazil. Pesquisa Veterinária Brasileira, 38(4), 629634. doi: 10.1590/1678-5150-pvb-5156.

Goff, J. P. (2008). The monitoring, prevention, and treatment of milk fever and subclinical hypocalcemia in dairy cows. The Veterinary Journal, 176(1), 50-57. doi: 10.1016/j.tvj1.2007.12.020.

Grummer, R. R. (1993). Etiology of lipid-related metabolic disorders in periparturient dairy cows. Journal of Dairy Science, 76(12), 3882-3896. doi: 10.3168/jds.S0022-0302(93)77729-77722. 
Herdt, T. H. (2000). Variability characteristics and test selection in herdlevel nutritional and metabolic profile testing. Veterinary Clinics: Food Animal Practice, 16(2), 387-403. doi: 10.1016/S0749-0720(15)301110 .

Hernandez-Urdaneta, A., Coppock, C. E., McDowell, R. E., Gianola, D., \& Smith, N. E. (1976). Changes in forage-concentrate ratio of complete feeds for dairy cows. Journal of Dairy Science, 59(4), 695-707. doi: 10.3168/jds.S0022-0302(76)84260-9.

Hove, H., Nørgaard, H., \& Mortensen, P. B. (1999). Lactic acid bacteria and the human gastrointestinal tract. European Journal of Clinical Nutrition, 53(5), 339-350.

Kleczkowski, M., Klucinski, W., Lutnicki, K., Jasinski, T., Jakubowski, T., Cegielkowska, M., \& Pietrzykowska, E. (2013). Effect of magnesium on its blood concentration in dairy cows transition period. XIII Middle European Buiatrics Congress, Belgrade, Serbia, 350-358.

Martinez, N., Risco, C. A., Lima, F. S., Bisinotto, R. S., Greco, L. F., Ribeiro, E. S., \& Santos, J. E. P. (2012). Evaluation of peripartal calcium status, energetic profile, and neutrophil function in dairy cows at low or high risk of developing uterine disease. Journal of Dairy Science, 95(12), 7158-7172. doi: 10.3168/jds.2012-5812.

Martinez, N., Sinedino, L. D. P., Bisinotto, R. S., Ribeiro, E. S., Gomes, G. C., Lima, F. S., \& Driver, J. P. (2014). Effect of induced subclinical hypocalcemia on physiological responses and neutrophil function in dairy cows. Journal of Dairy Science, 97(2), 874-887. doi: 10.3168/jds.2013-7408.

McGuire, M. A., Theurer, M., Vicini, J. L., \& Crooker, B. (2004). Controlling Energy Balance in Early Lactation. Advances in Dairy Technology, 16, 241.

Moallem, U., Folman, Y., \& Sklan, D. (2000). Effects of somatotropin and dietary calcium soaps of fatty acids in early lactation on milk production, dry matter intake, and energy balance of high-yielding dairy cows. Journal of Dairy Science, 83(9), 2085-2094. doi: 10.3168/jds.S0022-0302(00)75090-9.

Muller, L. D., Schaffer, L. V., Ham, L. C., \& Owens, M. J. (1977). Cafeteria style free-choice mineral feeder for lactating dairy cows. Journal of Dairy Science, 60(10), 1574-1582. doi: 10.3168/jds.S00220302(77)84073-3.

Ospina, P. A., Nydam, D. V., Stokol, T., \& Overton, T. R. (2010). Evaluation of nonesterified fatty acids and $\beta$-hydroxybutyrate in transition dairy cattle in the northeastern United States: Critical thresholds for prediction of clinical diseases. Journal of Dairy Science, 93(2), 546-554. doi: 10.3168/jds.2009-2277.
Pires, J. A. A., Delavaud, C., Faulconnier, Y., Pomies, D., \& Chilliard, Y. (2013). Effects of body condition score at calving on indicators of fat and protein mobilization of periparturient Holstein-Friesian cows. Journal of Dairy Science, 96(10), 6423-6439. doi: 10.3168/jds.2013-6801.

Reynolds, C. K., Aikman, P. C., Lupoli, B., Humphries, D. J., \& Beever, D. E. (2003). Splanchnic metabolism of dairy cows during the transition from late gestation through early lactation. Journal of Dairy Science, 86(4), 1201-1217. doi: 10.3168/jds.S0022-0302(03)73704-7.

Rodríguez, E. M., Arís, A., \& Bach, A. (2017). Associations between subclinical hypocalcemia and postparturient diseases in dairy cows. Journal of Dairy Science,100(9),7427-7434. doi:10.3168/jds.20 $16-12210$.

Schingoethe, D. J. (2017). A 100-Year Review: Total mixed ration feeding of dairy cows. Journal of Dairy Science, 100(12), 10143-10150. doi:10.3168/jds.2017 $-12967$.

Sordillo, L. M., \& Raphael, W. (2013). Significance of metabolic stress, lipid mobilization, and inflammation on transition cow disorders. Veterinary Clinics: Food Animal Practice, 29(2), 267-278. doi: 10.1016/j.cvfa. 2013.03.002.

van Knegsel, A. T., Van den Brand, H., Dijkstra, J., Tamminga, S., \& Kemp, B. (2005). Effect of dietary energy source on energy balance, production, metabolic disorders and reproduction in lactating dairy cattle. Reproduction Nutrition Development, 45(6), 665-668. doi: 10.1051/rnd:2005059.

Wildman, E. E., Jones, G. M., Wagner, P. E., Boman, R. L., Troutt, H. F., \& Lesch, T. N. (1982). A dairy cow body condition scoring system and its relationship to selected production characteristics. Journal of Dairy Science, 65(3), 495-501. doi:10. 3168/jds.S0022-0302(82)82223-6.

Wynn, S., Teramura, M., Sato, T., \& Hanada, M. (2015). Changes of serum calcium concentration, frequency of ruminal contraction and feed intake soon after parturition of dairy cows fed difructose anhydride III. Asian-Australasian Journal of Animal Sciences, 28(1), 58. doi: 10.5713/ajas.14.0418. 